these rights. This approach could require states to take positive measures to maintain or improve environmental quality to meet a standard compatible with respect for the right to private life.

The European Court has not yet gone so far as to require a state to undertake positive obligations. This may be due to the sensitivity of the court to the charge that it acts as a supranational body, which has made it wary of interfering in decisions made by states. The UK courts will not be under the same restraints and may adopt a more robust approach.

There are also indications of a willingness by the European Court to expand the scope to the right to life. In Association $X_{V}$ United Kingdom (application 7154/75 14 Eur Comn HR D\&R, 31, 32 [1979]), parents whose children had died or been severely injured as a result of vaccinations claimed that the British authorities had unjustifiably jeopardised the children's lives by not providing information on the risks of vaccination. The commission accepted that the state was obliged not only to refrain from taking life intentionally but also to take adequate steps to safeguard it. However, as the state had not intended the injuries, and adequate measures had been taken, the complaint was declared to be illfounded.

In Guerra v Italy Walsh J was of the view that art. 2 guarantees the protection of the bodily integrity of the applicants. Jambrek J saw the protection of health and physical integrity as being equally closely associated with the right to life as to the right to respect for private and family life. He was prepared to accept that the withholding of information about environmental risks could come within art. 2 and that the court's case law on art. 2 should start evolving in this respect.

Over time, an expansion of art. 2 may have the biggest effect on UK environmental law. The right to life could be invoked by workers claiming exposure to the risk of industrial accidents as a result of poor management systems or the use of chemicals whose toxicity is unknown. Similar principles will apply to risks from chronic pollution, as for example asthma caused by traffic, or exposure to asbestos dust or to pesticides.

\section{CONCLUSION}

There is certainly scope for the ECHR to affect the development of UK environmental law particularly with respect to creative uses of the right to life and the right to family and home life. The convention is also likely to perform the more nebulous task of keeping enforcement authorities on their toes in the light of the added weapon in the hands of plaintiffs.

Incorporation will not, however, resolve a number of underlying issues that make environmental litigation particularly difficult. These include valuing loss to the environment and linking the complex scientific explanations for pollution to legal concepts of causation.

\section{Justine Thornton \& Stephen Tromans Simmons \& Simmons}

\title{
Human Rights
}

\section{Protection from discrimination: the European dimension}

\section{by Geoffrey Bindman}

The government's intention in the Human Rights Act 1998 is to make the rights protected by the European Human Rights Convention (EHRC) enforceable in domestic law. This is to be achieved by requiring public authorities to act in conformity with those rights and by giving the courts the right to determine whether or not they have done so. Judges must interpret both common law and statute law to give effect as far as possible to those rights. Only when a statute cannot be so interpreted will the courts be powerless to implement the convention. In that situation their role will be limited to making a declaration of incompatibility, which it will be for Parliament to correct. The domestic courts will not be bound by decisions of the European Court of Human Rights but they must take them into account.
The rights to be incorporated are only those set out in the convention. Surprisingly, these do not include the right not to suffer discrimination on racial or other arbitrary grounds. The convention provides in art. 14 merely as follows:

'The enjoyment of the rights and freedoms set forth in this convention shall be secured without discrimination on any ground such as sex, race, colour, language, religion, political or other opinion, national or social origin, association with a national minority, birth or other status."

Yutaka Arai, in an article in Amicus Curiae November 1998, at p. 6, explained how art. 14 has been interpreted by the European Court and Commission of Human Rights and demonstrated that they have given it a broad interpretation wherever possible, even to the extent of holding that a breach of art. 14 can occur where no violation of a substantive right has been proved. Nevertheless the absence of a substantive right to be free of discrimination in the convention is a severe restriction on its effectiveness as a safeguard against unfair discrimination.

The limited protection against discrimination in the convention reflects a general lack of concern about discrimination in Europe as a whole at the time when the convention was introduced in 1950. Notwithstanding the recent terrible experience of the Holocaust, politicians failed to recognise any role for the law in the protection of ethnic minorities. Such groups were often perceived in terms of nationality or citizenship, and there was a long-standing assumption that discrimination on those grounds was legitimate and a proper exercise of national sovereignty. 
Freedom from discrimination on grounds such as race, gender, and disability has been established as a fundamental human right at least since 1948. The Universal Declaration of Human Rights in its first paragraph asserts the equal rights of all members of the human family. Section 26 of the International Covenant on Civil and Political Rights - an instrument intended to amplify a major part of the declaration into an enforceable code - requires its signatories:

'to prohibit any discrimination and guarantee to all persons equal and effective protection against discrimination on any ground such as race, colour, sex, language, religion, political or other opinion, national or social origin, property, birth or other status.

The International Convention on the Elimination of All Forms of Racial Discrimination (1965) and the similar convention restraining discrimination against women (1979), both ratified by the UK, elaborate on these obligations.

Domestic law in the UK gives a high level of protection against discrimination through the Sex Discrimination Act 1975 (SDA), the Race Relations Act 1976 (RRA), the Disability Discrimination Act 1995 (DDA) and the domestic implementation of EC law as embodied in art. 119 of the Treaty of Rome and a series of directives.

The Human Rights Act 1998 will be essentially a procedural measure which will embody in domestic law the rights already vested in those living in the UK by reason of its adherence to the EHRC. However, though in theory it confers no new rights, it is likely to have a significant impact on the ability and willingness of UK residents to assert and even expand convention rights in ways which could not be achieved through the current enforcement machinery available only in Strasbourg

\section{CREATING A CULTURE OF HUMAN RIGHTS}

The intention of the government is that a 'culture' of human rights will be created. This seems to mean an awareness among the public that they possess fundamental rights and that they can assert them against anyone, especially the state and its surrogates. Few lawyers, let alone the public at large, are currently familiar with the convention and, even in the rare cases where the possibility of a remedy at Strasbourg is considered, the practical difficulties and procedural delays often rule it out. Legal aid is available from the European Human Rights Commission but it is very limited and not usually available until an advanced stage in the process. The fact that convention rights can be claimed in domestic courts will obviously encourage reliance on them and, anticipating that arguments based on the convention will increasingly be relied on, the government is embarking on a programme of judicial education (at the estimated cost of up to $£ 4.5 \mathrm{~m})$.

The act will make it unlawful for a public authority to act in a way which is incompatible with a convention right. The courts and industrial tribunals will be treated as public authorities for this purpose. This may mean that courts and tribunals must consider of their own motion convention rights arising in cases before them, whether or not raised by the parties. If so, how could such a duty be enforced and what are the consequences of breach? These are among a number of issues the courts will themselves have to resolve when the act comes into force.

Notwithstanding the 'sitic' status of discrimination in the convention, and notwithstanding the wide scope of domestic anti-discrimination law, incorporation will open the way for a number of discrimination issues to be litigated.

In the first place, the scope of the discrimination covered by art. 14 is much wider than in domestic law. Domestic law restrains discrimination on grounds of 'colour, race, nationality or ethnic or national origins'; on grounds of sex (i.e. gender) or marital status; and on the ground of disability, but discrimination on all other grounds is lawful. Article 14 covers discrimination on any ground:

'such as sex, race, colour, language, religion political or other opinion, national or social origin, association with a national minority, property, birth, or other status.'

The words 'such as' will allow the courts to treat discrimination on the ground of sexual orientation as unlawful in suitable circumstances.

Although, as Yutaka Arai has shown, it may not be necessary to prove violation of a substantive right or freedom protected by the convention, a direct link with such a right or freedom must be shown and that will not be easy. Sometimes a blatant case of discrimination may, of itself, be a violation of art. 3 (prohibition of inhuman or degrading treatment). The commission itself endorsed this possibility in its report on the East African Asians case in 1973. Article 4 (prohibition of slavery and forced labour) and art. 6 (the right to a fair trial) may be relied on to support other discrimination claims. In cases of race and sex discrimination, the effect of the Human Rights Act will not be to make new remedies available but to supply the impetus to seek those which already exist.

\section{IMPACT OF EC LAW}

There has already, of course, been a considerable impact from European law on anti-discrimination law through EC law. In relation to sex (or rather gender) discrimination, this has largely been the product of art. 119 of the Treaty of Rome which provides for equal pay for equal work as between men and women, and a series of directives, covering equal pay, equal treatment pregnancy, and social security. The directives are enforceable only against the government, which, however, has been obliged to introduce legislation to implement them. The impact on racial discrimination has been only marginal or consequential. The ECJ decision in Marshall (Marshall $v$ Southampton and South-West Hampshire Area Health Authority (Case C-271/91, [1993] 2 CEC 378) for example, which held that the limit in the SDA on the amount of compensation awards violated art. 119, had an immediate binding effect on UK courts but did not apply to racial discrimination cases, although the statutory provisions in the RRA were virtually identical to those of the SDA. In practice the anomaly could not survive and was removed by Parliament, the government accepting a private members' bill.

By virtue of the European Communities Act 1972, community law and decisions of the ECJ are binding on UK courts and tribunals. No parallel is proposed for the Human Rights Convention and courts and tribunals will continue to be obliged to implement UK statute law even when it is incompatible with the convention. Only the High Court may issue a certificate of incompatibility in such a case, leaving it to Parliament, should it 
choose to do so, to pass amending legislation. An accelerated process is provided but it is left to the discretion of the relevant minister to choose to invoke it.

The convention is not part of community law, though the European Court of Justice has acknowledged that its principles are of broad application and art. 5 of the Treaty of European Union (inserted by the Amsterdam Treaty) requires member states to respect the rights guaranteed by the convention. Of greater likely impact on antidiscrimination law is art. 13 of the Amsterdam Treaty which reads as follows:

'Without prejudice to the other provisions of this Treaty and within the limits of the powers conferred by it upon the Community, the Council, acting unanimously on a proposal from the Commission after consulting the European Parliament, may take appropriate action to combat discrimination based on sex, racial or ethnic origin, religion or belief, disability, age or sexual orientation.'

The Amsterdam Treaty has not yet been ratified and ratification by all member states is unlikely to have been completed before 1999. Although the treaty will not come into force until then preparations are already under way to prepare community legislation in anticipation. That is likely to take the form of a directive which will set minimum standards for domestic legislation in the member states on discrimination. Article 13 of the Amsterdam Treaty covers areas of discrimination which are not touched on at all by current UK domestic law. Discrimination on grounds of sex, racial and ethnic origin, and disability are prohibited (to a greater or lesser degree) by the SDA, the RRA and the DDA but no legislation prohibits discrimination on grounds of religion or belief, age, or sexual orientation.

\section{EUROPE WIDE STANDARDS}

Article 13 provides an opportunity which has long been sought to establish standards for anti-discrimination laws throughout Europe. There is, of course, no compulsion on the community to act. There must be unanimity among the member states and the difficulties of establishing a consensus, especially on an issue which arouses religious and cultural conflicts, should not be underestimated.
The first stage in the process is a proposal from the commission upon which the European Parliament must be consulted. The directorate-general for research of the Parliament has already produced a draft paper entitled Towards an EU antiracist policy which indicates possible directions in which the matter may proceed and the informal group of experts calling itself 'the Starting Line' has published a draft directive which it will invite the council to adopt. The Starting Line's recently published pamphlet (Proposals for Legislative Measures to Combat Racism and to Promote Equal Rights in the European Union edited by Isabelle Chopin and Jan Niessen (Commission for Racial Equality, 1998)) containing this draft argues that a council directive is the preferable form of community legislation. Its purpose is to set standards rather than to prescribe the precise content of national legislation. The alternative mechanism is a regulation. The legal systems and cultures of the member states differ widely and a regulation would be unduly prescriptive.

The draft directive covers discrimination on the grounds of both race and religion but does not touch on the other areas in art. 13. These raise separate questions which lead the drafters to consider that they should be dealt with in separate directives.

Broadly, the directive follows the pattern of UK domestic antidiscrimination legislation. It begins with a useful definition of racial and religious discrimination as:

'any distinction, exclusion, restriction or preference which has the purpose or the effect of nullifying or impairing the recognition, enjoyment, or exercise of human rights and fundamental freedoms or participation in the political, economic, social, cultural, religious life or any other public field on grounds of racial or ethnic origin or religion or belief.'

Direct and indirect discrimination are defined as in UK legislation but removing some weaknesses in the definition of indirect discrimination. Member states are required to take necessary measures in conformity with their legal systems to prohibit:

- discrimination of the kinds mentioned above;

- incitement or pressure to racial or religious discrimination by private individuals or bodies and by public authorities and institutions; and

- the establishment, operation, membership or support of any organisation promoting such incitement.

Member states are required to provide effective judicial remedies and to establish bodies (like the Commission for Racial Equality (CRE) and Equal Opportunities Commission (EOC)) to investigate and pursue complaints.

These are of course merely the proposals of an independent group, albeit one which is highly respected within the community institutions. There is no certainty that these or any other progressive proposals will be accepted, especially bearing in mind the requirement of unanimity.

If a directive is adopted it will have more impact on other European states than on the UK whose legislation already complies with most of its provisions. Nevertheless it would bring about a significant strengthening of antidiscrimination law. It would of course extend the scope of the law to religious discrimination, but it would also extend the obligations of public authorities in relation to racial discrimination. They are exempted under current law in respect of many activities (see, for example, $R v$ Entry Clearance Officer, Bombay, ex $p$ Amin [1983] 2 AC 818). Further directives on disability, age and sexual orientation would also compel substantial extensions of UK anti-discrimination law.

There is, of course, no reason why the same extensions could not be achieved by domestic legislation. The Home Office is already reviewing the current law and is considering detailed and powerful recommendations recently submitted by the EOC and the CRE. It would be preferable to put our house in order now, in conformity with our wider international obligations, rather than wait for European compulsion.

Geoffrey Bindman

Bindman \& Partners 